\title{
BENEFITS OF KPIS FOR INDUSTRY SECTOR EVALUATION: THE CASE STUDY FROM THE CZECH REPUBLIC
}

\author{
Martina Hedvičáková, Martin Král
}

\section{Introduction}

Industrialization, a major force in structural change, shifts resources from labour-intensive activities to more capital technology-intensive activities. It will remain crucial to the future growth of developing countries. Manufacturing's share of GDP has remained stable over the last 40 years. Technology and capital equipment are the main drivers of both manufacturing growth and aggregate growth in developed and developing countries, although in developing countries energy and natural resources use affects growth in the medium- and low-tech industries (Unido, 2018).

Currently, the industrial value creation is shaped by the development towards the fourth stage of industrialization, so-called Industry 4.0. Industry 4.0, referred to as the "Fourth Industrial Revolution", also known as "smart manufacturing", "industrial internet" or "integrated industry", is currently a muchdiscussed topic. It is assumed that Industry 4.0 supposedly has the potential to affect entire industries by transforming the way goods are designed, manufactured, delivered, and paid for (Stock \& Seliger, 2016; Hofmann \& Rüsch, 2017; Marešová, et al., 2018; Hedvicakova, 2018; Hedvicakova \& Kral, 2018). Substitution of capital for labour leads to the onset of a new concept of Industry 4.0, which is already being promoted in most European Union countries.

Industry creates long-term less than a third of gross value added of the whole of the Czech national economy. Relatively stable share in the last 20 years. Industry accounts for about 30\% of total employment in the Czech Republic. For this reason, we focused on the analysis of the industry in the Czech Republic.

Czech industry is at the beginning of 2017 was characterized by high dynamics, significantly exceeding the previous year's pace and follow rather a very successful year 2015 .
In Q2 and Q3 2017 is already a noticeable decline in dynamism. The industrial production index was in the EU28 2.9\% and in the Czech Republic 5.9\% (January to September 2017) (Statistika\&My, 2018). Value added in the industry in the first quarter of 2018 after the first five years fell slightly year-on-year by $2.3 \%$. The pace has slowed down and in the second and third quarters of 2018 , it has stabilized on a more moderate but sustainable growth. In the second and third quarters of 2018, the growth in value added stabilized around two to three percent. In the 1 st to the 3rd quarter of 2018, the value added increased year-on-year by $0.9 \%$ at current prices. The major weight in the industry continues to be maintained by large enterprises with 250 or more employees. Business entities of this size category accounted for $67.2 \%$ of total revenues in the 1 st to 3 rd quarters of 2018 , $69.7 \%$ of total industrial outputs; the share of value added was $60.9 \%$ (Statistika\&My, 2019).

\section{Theoretical Basis}

Currently, there is a dynamic and progressive growth of substitution labour by capital. The introduction of new technologies, digitization, and automation of production is referred to as the fourth industrial revolution or Industry 4.0. The initiative Industry 4.0 also causes changes in the labour market. Industry 4.0 should increase production efficiency, increase work productivity, reduce costs, customize solutions, and increase business flexibility. The higher efficiency of production and automation will enable the implementation of sustainable development. These market changes bring with them the need to measure the efficiency and performance of production and industry. Current performance indicators are insufficiently reflected in dynamically changing market conditions. For this reason, more and more companies, as well as governments around 
the world, are starting to use performance indicators and efficiency for example KPI.

KPIs are objective-oriented quantitative assessment indicators, which are regarded as a classification of key ingredients in the operations of the enterprise. In recent years, the business environment has become more competitive and volatile. Therefore, enterprises need to focus on technological abilities, the soft abilities, and management of manpower. The knowledge technology of an enterprise can lead to competitive advantage and in surmounting the competition. Thus, the concept of core competence becomes an important management tool (Lahti, 1999; Hong et al., 2015).

A Performance Indicator or Key Performance Indicator (KPI) is a term used by industry or professionals for assessing or type of performance measurement. KPIs are generally used by an organization in terms to evaluate their success and also the success of a particular effort which an individual or they are doing. Although success is sometimes defined in terms of making progress toward the expected goals or an event that accomplishes its intended purpose but often, success is simply the repeated achievement of some level of operational goal and workers it becomes all the more important to set strategic goals, so choosing the correct KPIs is directly dependent on gaining an understanding of what is important to the organization (Srivastava \& Maitra, 2016).

Currently, dashboards are the preferred tool across organizations to monitor business performance. Dashboards are often composed of different data visualization techniques, amongst which are Key Performance Indicators (KPIs) which play a crucial role in quickly providing accurate information by comparing current performance against a target required to fulfil business objectives. However, KPIs are not always well known and sometimes it is difficult to find an appropriate KPI to associate with each business objective (Peral et al., 2017).

Manufacturing industries today are focusing on controlling negative environmental impacts, reducing cost, conserving energy and natural resources while producing new products through various methods and tools of Sustainable manufacturing assessment. Singh and Sultan (2018) propose science-based guidelines for modelling and evaluation of key performance indicators (KPIs) in an aluminium extrusion process. The proposed methodology consists of the following main components: 1 identification of key performance indicators 2) classification of manufacturing processes on the basis of KPIs 3) evaluation of key performance indicators.

Kaganski et al. (2017) point out that the amount of different available metrics provides difficulties to make the right decisions. Ammara et al. (2016) developed new key performance indicators (KPIs) based on an in-depth characterization and dimensional analysis of the Kraft process equipment using the Buckingham $\mathrm{Pi}$ Theorem.

An alternative to benchmarking is to identify the process signals that are strongest correlated with the KPI and then change these process signals in the direction that improves the KPI (Lindberg et al., 2015).

Key Performance Indicators (KPIs) are crucial for measuring and improving the performance of the manufacturing process. An especially critical aspect of developing balanced process performance improvement strategies across all critical objectives is the need to discover the inherent relationships between all KPls assigned to a targeted manufacturing process (Brundage et al., 2017; Kang et al., 2016).

Amrina and Yusof (2011) propose a set of initial key performance indicators (KPIs) for sustainable manufacturing evaluation believed to be appropriate to automotive companies, consisting of three factors divided into nine dimensions and a total of 41 sub-dimensions. Four of the most commonly cited indicators to evaluate manufacturing performance are quality, cost, delivery, and flexibility (Hudson et al., 2001). Finally, the initial KPIs consist of three factors of environmental, economic, and social performance and further divided into nine dimensions.

\section{Methodology and Goals of Article}

Secondary data monitored in a detailed breakdown since 2008 from the Ministry of Industry and Trade of the Czech Republic are used in this paper. These data contain basic characteristics of individual types of industry (i.e. everything related to the mechanical, physical or chemical transformation of materials or components into new products). This includes, in particular, the added value, costs, 
turnover, profits, the number of companies operating in the industry, the number of their employees and the investment.

The aim of the paper is to critically assess the performance evaluation of individual industries based on the absolute monitored indicators compared to the performance indicators (PIs) and key performance indicators (KPIs). The paper contains a proposal for a KPIs system that would allow performance assessments of industry sectors, including a correlation analysis of these indicators, to allow for long-term relations. Therefore, it is possible to evaluate the performance of individual industry sectors by means of their aid.

Performance Indicators (PIs) are set and used for the analysis. These performance indicators are based on absolute indicators that are monitored by the Ministry of Industry and Trade (2018a; 2018b) and the Czech Statistical Office (2019) for the evaluation of the development of the manufacturing industry. They draw on experience in setting performance indicators, for example in the area of the private sector and public administration, in monitoring the economic (financial and cost) effectiveness of different areas. The absolute values of the monitored indicators are therefore related to other absolute values of the indicators (e.g. number of employees, total costs, total investments, etc.), thus generating the ratios commonly used in various financial analyses (Balachandran \& Williams, 2018).

These are index ratios that allow more appropriate managerial comparison of the performance and efficiency of individual industry sectors. These are relative ratios that take into account individual absolute characteristics and, in addition, cost-efficiency or the promotion of industry 4.0 through investment replacement labour by capital. At the same time, a correlation analysis of these PIs is performed in the most important industrial sectors and an analysis of the contrast between the simple evaluation of the performance of these sectors according to the raw data and the set PIs. The correlation analysis is performed in IBM SPSS Statistics, using the Pearson correlation coefficient. The analysis complements the graphical representation of the performance of major industries in the Czech Republic, the statistics standardized by standard deviation are used in the figures.

On the basis of correlation relationships, three key performance indicators with the lowest correlation coefficients are selected to allow the most comprehensive way to evaluate performance. According to these key indicators, the performance of the industrial sectors of the Czech Republic is subsequently assessed, notably with the emphasis on the volatility of the development of KPIs for individual industrial sectors since 2008. On the basis of the significance of changes in growth indexes (year I (year-1)) for KPIs for each year, it is concluded what type of industrial sectors are threatened by a potential economic recession that may occur in the Czech Republic in the future, and, on the contrary, which sectors are stable and even in the event of a future recession or crisis are perspective for the Czech economy.

\section{Current Economic Situation in the European Union and in the Czech Republic}

The beginning of the Fourth Industrial Revolution, information and communication technologies, become crucial in both the processing industry and the services (Půžová \& Marešová, 2014). Their impact on GDP growth and regional development is evidenced by several studies (Gatautis, 2008; Volejníková \& Lelek, 2012; Doucek, Maryška, \& Novotný, 2013; Kraftová, Doudová, \& Miláček, 2018).

Structure of economic sectors and industries, or disciplines have long been an important element in the performance assessment of national economies (Fisher, 1939; Marais, 1981; Saboniene, 2010). Zdražil and Applová (2016) identify even across the EU $\sigma$-convergence in terms of gross domestic product (GDP) growth, productivity and employment, although it does not confirm this at the national level for the V4 countries as part of the so-called eastern integration expansion (Kraftová, Doudová, \& Miláček, 2018).

\subsection{The Situation in the European Union}

At the NACE division level, the manufacturing sector is composed of 24 different subsectors. The largest EU-28 subsectors in 2015 in terms of value added and employment were the manufacture of machinery and equipment (Division 28), manufacture of motor vehicles, trailers and semi-trailers (Division 29) and manufacture of food products (Division 10) (Eurostat, 2018a). 
Manufacturing subsectors are very diverse, combining activities with relatively low apparent labour productivity and average personnel costs, such as the manufacture of wearing apparel, leather products, furniture, wood and of products of wood and cork and textiles, with other activities that have considerably higher values for the same indicators, such as manufacture of coke and refined petroleum products, tobacco manufacturing, the manufacture of basic pharmaceutical products and pharmaceutical preparations and the manufacture of chemicals (Eurostat, 2018a).

In 2015, apparent labour productivity within the EU-28's manufacturing subsectors ranged from EUR 20.0 thousand per person employed or more for the manufacture of wearing apparel, furniture, leather and related products, and wood and products of wood to EUR 204.0 thousand per person employed for the manufacture of coke and refined petroleum products (Eurostat, 2018a).

Among the five largest EU Member States, Germany stood out as its manufacturing sector contributed more than one quarter $(30.4 \%)$ of the EU-28's value added in 2014, well above its $23.3 \%$ share of value added in the EU-28's non-financial business economy as a whole. Italy also recorded a larger share $(11.9 \%)$ of the value added generated in the EU-28's manufacturing sector than it did for the nonfinancial business economy as a whole (9.8\%), while the reverse was true for France and the United Kingdom (Eurostat, 2018).

Among the EU Member States, the highest apparent labour productivity in manufacturing in 2015 was recorded in Ireland, where this measure reached EUR 445.9 thousand per person employed. This was quite ahead of the next highest level of apparent labour productivity, namely EUR 103.5 thousand per person employed recorded in Belgium. In Norway and Switzerland, the apparent labour productivity in manufacturing was above the EU-28 average, and in the case of Norway, the average personnel costs (EUR 68.1 thousand per head) were higher than the figures for the EU Member States. Belgium recorded the second highest level of average personnel costs within the manufacturing sector in 2015, EUR 63.6 thousand per employee, just above the value of EUR 63.1 thousand per employee in Sweden. Average personnel costs were also greater than or equal to EUR 50.0 thousand per employee in the Netherlands, Luxembourg, Austria, Germany, France, Ireland, Denmark and Finland. On the other hand, average personnel costs were below EUR 10.0 thousand per employee in Latvia, Romania and Bulgaria where the lowest levels were recorded (EUR 5.7 thousand per employee). Combining these two indicators gives the wage-adjusted labour productivity ratio, which is a measure of labour productivity that takes into account the very different levels of pay and social charges between the Member States and activities. The highest such ratios were recorded in Ireland (840.9\%), Hungary (223.8\%), Bulgaria (200.9\%), the United Kingdom (193.3\%) and Poland (192.1\%). The lowest wage-adjusted labour productivity ratios in manufacturing were registered in France (130.2\%), Germany $(133.6 \%)$, Luxembourg $(135.4 \%)$ and Italy (138.8\%) (Eurostat, 2018a).

\subsection{The Situation in the Czech Republic}

The Czech economy growth has been accelerating since 2013, and it has been supported mainly by the domestic demand. The gross domestic product (GDP) adjusted for price effects and seasonally adjusted in 2017 (Q4) was by $0.5 \%$ higher than in the previous quarter and compared to the corresponding quarter of 2016 it was $5.2 \%$ up. The GDP growth for the entire year 2017 was $4.5 \%$.

The gross value added (GVA) increased by $0.6 \%$, quarter-on-quarter (q-o-q), and by $5.4 \%$, year-on-year (y-o-y). Manufacturing industry was successful; it was mainly owing to the manufacture of motor vehicles, electrical equipment, metal structure, and chemical products. Performance of manufacturing increased by $0.9 \%$, q-o-q, and by $7.4 \%$, y-o-y. The GVA in most economic activities of services was also slightly growing compared to the Q3 (see Tab. 1) (Czech Statistical Office, 2018).

The position of industry in the structure of the Czech economy can be documented by the share of this sector of total gross value added (at current prices).

On the resource side, gross value added increased at constant prices yearon-year by $4.7 \%$, i.e. as well as the gross domestic product. She was still doing well the manufacturing industry, which added $7.9 \% \mathrm{y} / \mathrm{y}$ and almost secured half of the total gross value added. All services, including trade, transport, accommodation and hospitality, which turned 


\begin{tabular}{l|c|c|c|c|c} 
& Q1 & Q2 & Q3 & Q4 & 2017 \\
\cline { 1 - 5 } Compared to the previous quarter & 1.6 & 2.2 & 0.8 & 0.6 & \multirow{2}{*}{4.5} \\
\cline { 1 - 5 } Compared to the corresponding quarter of 2016 & 3.0 & 4.6 & 5.2 & 5.4 & \\
\hline
\end{tabular}

the trend after three quarterly declines. Growth has also returned to construction, with a drop in gross value added over the entire year.

In the sectoral structure, gross value added (in nominal terms) slightly has weakened almost a third of the industry, despite its gross added value grew by $6.6 \%$ in the second quarter, well above the gross value added across the economy. The decrease in the share (to $32 \%$ ) was caused by the decrease in prices in the industry by $1.3 \%$, while the average price level on the supply side of the economy increased by $0.9 \%$. In in the manufacturing industry, prices fell even by $2.4 \%$, so even a dynamic one its performance did not prevent a slight deterioration in this relative indicator (down to $26.9 \%$ ). By contrast, above-average growth in prices in the trade and transport sector (by $2.5 \%$ ) improved the position of this industry (to $18.9 \%$ ), although its gross added value grew more slowly $(4.1 \%)$ than in the whole economy (Ministry of Industry and Trade, 2018a).

Approximately 1.1 million employees work in the manufacturing industry in the Czech Republic, but this number has not changed significantly - it has only increased by $8 \%$ since 2010 (see Fig. 1). On the other hand, however, the overall added value of the Czech industry - from CZK 728 billion in 2010 to CZK 1,020 billion in 2016, an absolute increase of nearly $40 \%$. Still, the development of the manufacturing industry in the Czech Republic was marked by the global financial crisis almost ten years ago, in the past few years the EBIT reached a record CZK 330 billion and is rather stagnant. The same is true for investments that are directed to the industry. While in 2010 they were only CZK 140 billion, in the years 2015 and 2016 they grew to a total of CZK 220 billion. However, it is necessary to add that the ratio of investments to total costs still does not reach the level of the global financial crisis and still oscillates around $5 \%$. In 2008 , this ratio was $6.5 \%$, two years later (when the absolute level of investment reached the ten-year low) was only $4.5 \%$ and in 2016 only $5.3 \%$ more than $5.3 \%$ (Ministry of Industry and Trade, 2018b).

\section{Results}

In the Czech Republic, for the longest time, most people are employed by companies operating in the motor vehicle manufacturing industry,

\section{Fig. 1: Basic characteristics of the industry in the Czech Republic}

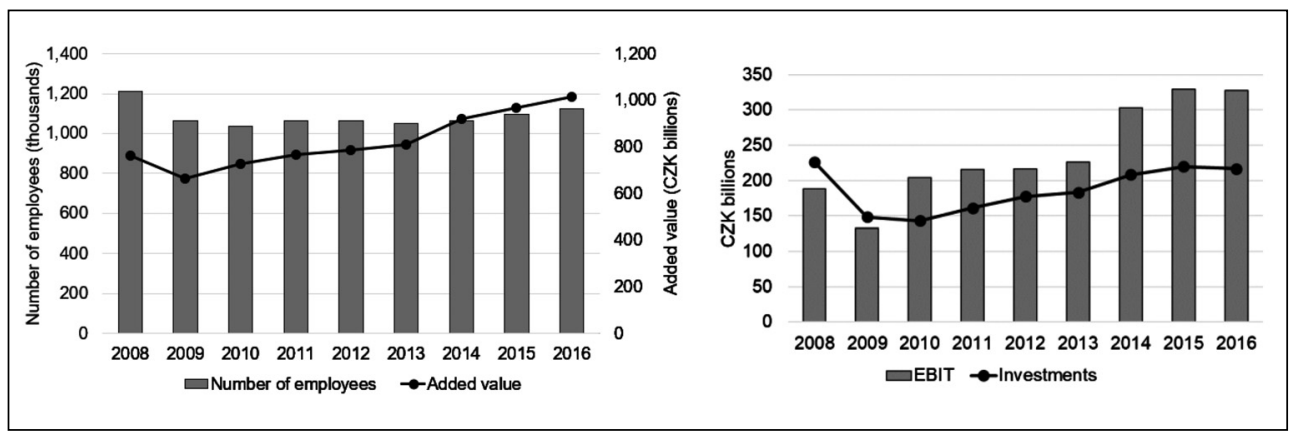




\section{Fig. 2: Main industry sectors in the Czech Republic}

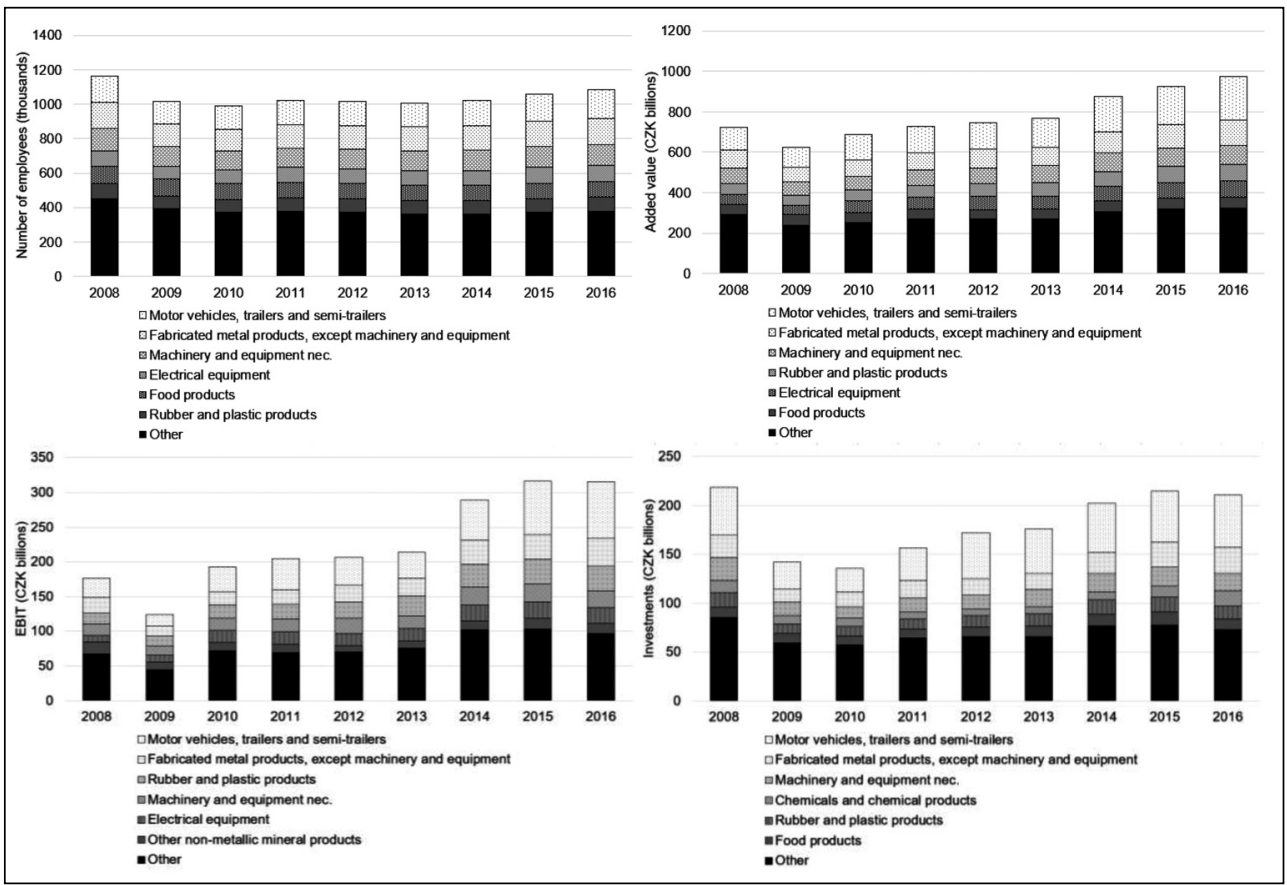

Source: own processing

the production of metal structures and metal products and the production of metal machinery and equipment. In these three sectors, more than $40 \%$ of people working in the industry are employed (see Fig. 2). On the other hand, only $3 \%$ of people work in papermaking or clothing production, due in particular to low-cost competition and imports from Asian countries.

High contrast can also be found from the point of view of the total turnover of companies operating in the industry. The first three industries are relatively stable, accounting for almost $46 \%$ of the industry's total revenue, while for example, the already mentioned paper industry and the clothing industry account for only $2.5 \%$. Similarly, we can continue to compare the investments where the ratio is from $46.6 \%$ to $2.4 \%$ or the added value, where the ratio is from $44.6 \%$ to $2.6 \%$.

From this basicanalysis, there is a correlation between the size of individual industries and their contribution to GDP: the high number of employees indicates the high costs, high sales, high investments, and the total added value. These implications are also demonstrated by the correlation analysis of individual monitored indicators, basically very strong and statistically significant (level of significance alpha $=0.01$ ) correlation of approximately 0.9 are between these indicators. These relationships can be observed in the graphical representation (for comparability of individual statistical characteristics the data were standardized, the individual axes represent normalized variables) (see Fig. 3).

However, without any more detailed analysis, there is not possible to determine any larger industry as efficient, because even a company that employs a low number of employees can create a high added value, even though the cost is lower compared to other businesses. Evaluating the performance of each sector and estimating its economic benefits is therefore not possible by using regression analyses for example because that would only prove the above-mentioned dependency. 


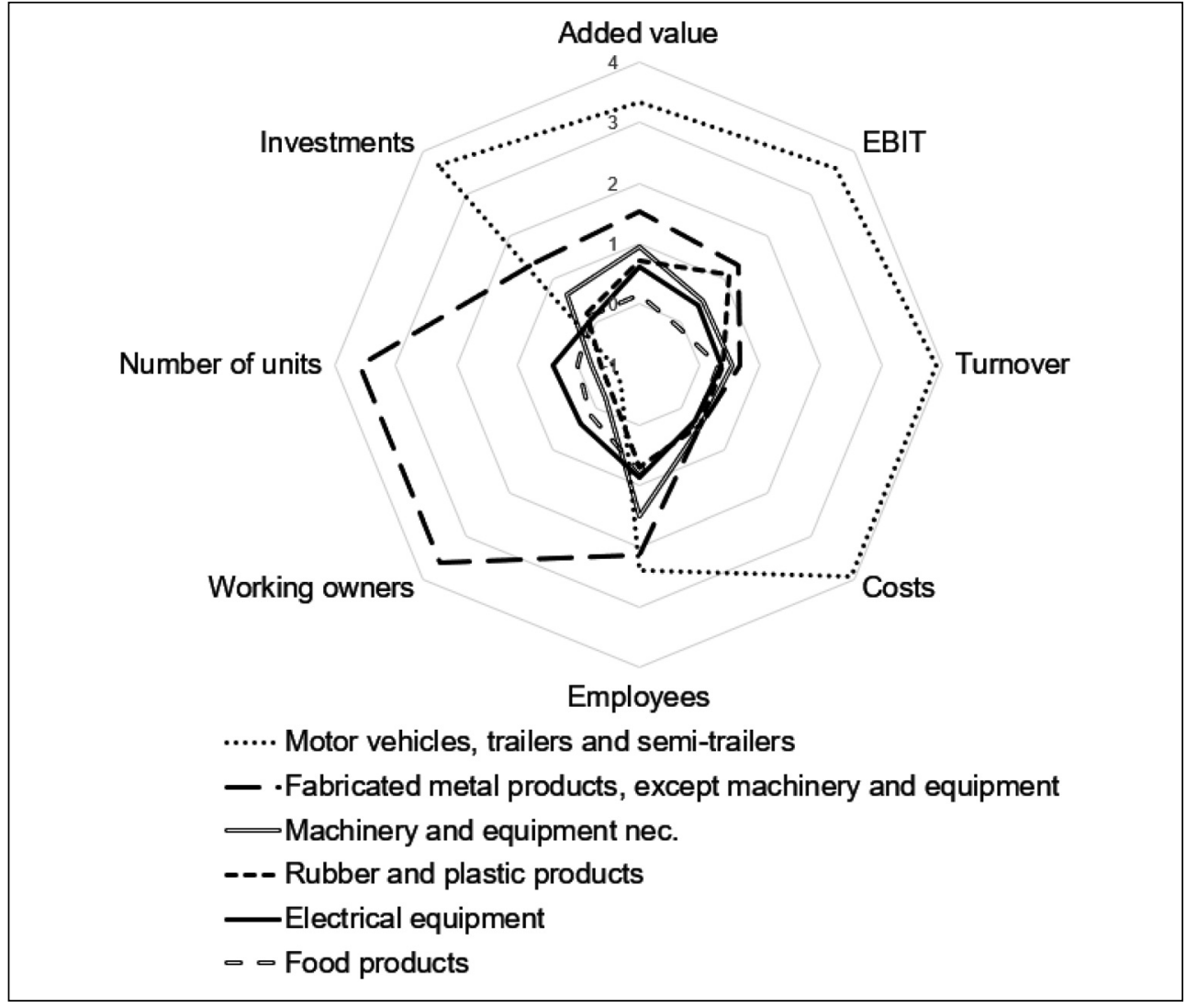

Source: own processing

For this reason, it is necessary to evaluate the performance in a different way - using the so-called Performance Indicators (PIs) and Key Performance Indicators (KPIs) that are used, for example, by Governments of different countries for a number of different areas (e.g. Great Britain to assess the efficiency of using office buildings (Government Property Agency, 2018), in the Czech Republic for evaluating the effectiveness of elections (Král \& Hájek, 2018) etc.). These are benchmarks that together create a performance rating system that is more usable than a managerial perspective not only for individual companies but also for entire sectors - it can serve to support industries that are successful in maintaining a comparative or absolute advantage, and on the contrary, leaving the sectors that are not efficient.

By using all the main indicators followed by the Ministry of Industry and Trade and the Czech Statistical Office, we have subsequently set the following performance indicators (ratios) to assess the area of industry:

- Value added per employee, which reflects technological progress (in the context of industry 4.0 replacement of labour by capital), over time should be in a positive correlation with the performance of the industry;

- Value added in relation to cost, which expresses cost-effectiveness, similar to the previous indicator, there should be a positive correlation between this indicator and the performance of the industry; 


\section{Business Administration and Management}

- The turnover per employee, which reflects the work efficiency of employees, there should again be a positive relationship between this indicator and the performance of the industry;

- Earnings before taxes and interest (EBIT) per employee, which complements the previous indicator, takes into account the level of costs;

- Investment per employee, which reflects the degree of innovation in the context of industry 4.0, as investments are the source of future revenue and performance gains;

- A share of investments of the total costs, which is similar to the previous indicator (the rate of innovation);

- Value added in relation to investments, which expresses the effectiveness of the investment, thus enables it to determine whether investments in the industry share the same economic benefits and lead to added value;

- EBIT in relation to investments, which complements the previous indicator as it also takes into account total costs.

These performance indicators can be referred to as so-called ratio indicators. Ratio indicators are used for performance evaluation in many areas of private and public administration (Ministry of Interior, 2016). In summary, these indicators can be used in a relatively simple way to perform complex performance assessments (Balachandran \& Williams, 2018). These indicators together create a system of indicators that can be used to assess the performance of individual industries as a whole, while making decision-

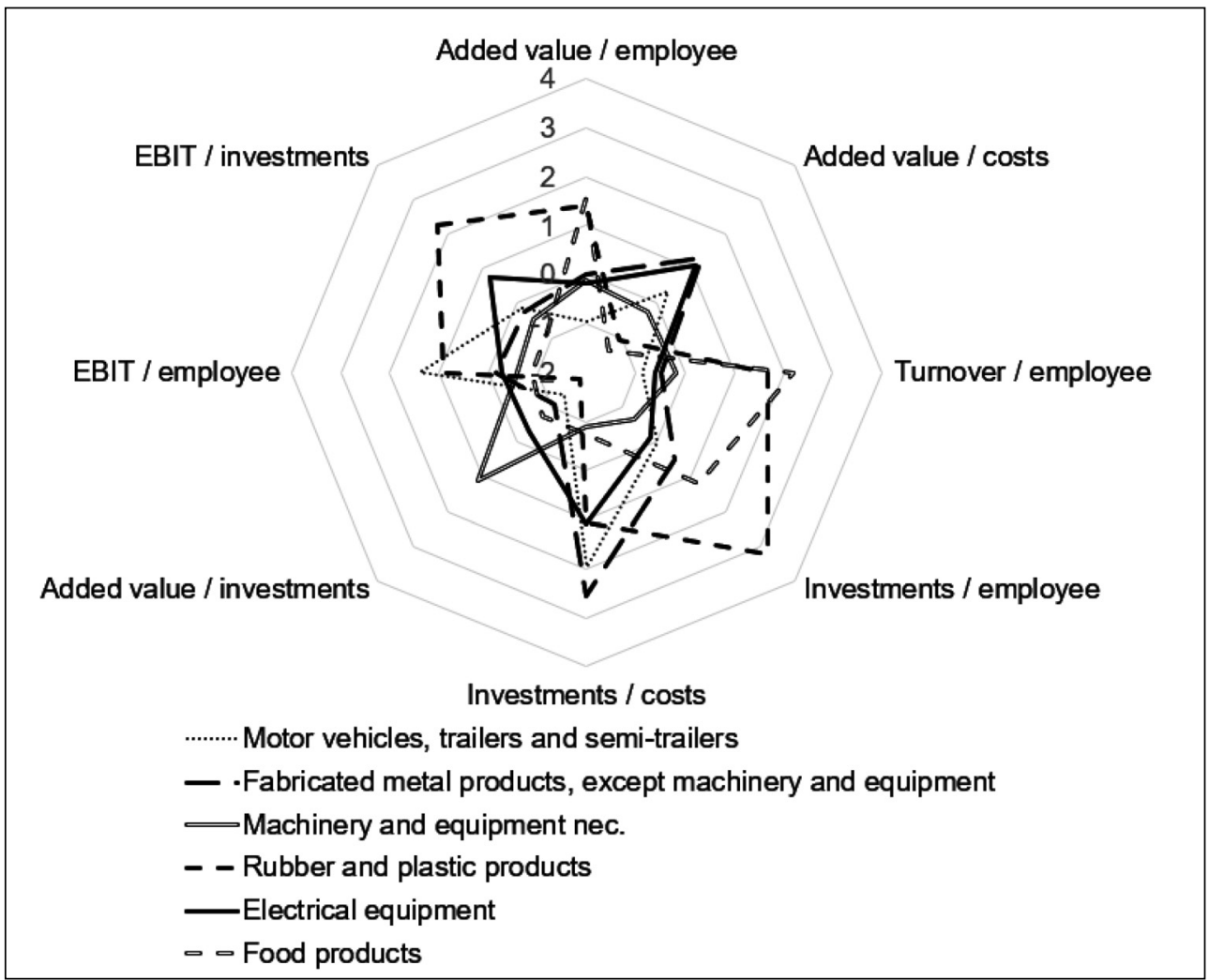


making at the level of individual companies, both in benchmarking and government policy support for the relevant sectors.

The following graph (Fig. 4) shows a significant difference in performance between industries compared to the above (the same industries are shown, and the normalized values of the relevant PIs are used).

While the automotive industry has the highest revenue, it is rated very poorly in terms of value added per employee, which is due to the very high number of employees that make the resulting benefit diminish. Similarly, this is the case for turnover per employee or investment per employee. According to these indicators, it is possible to say that the profit of a successful industrial sector is satisfactory even in terms of the number of employees, but it does not reach its potential because of its low level of automation. Activities that could be provided by modern technology are in this case people whose employment is generally more expensive.

On the other hand, for example, food production, which ranks among the smaller industries, has a completely different position in the KPIs. It turns out that in terms of employees it has a high added value, turnover

\section{Tab. 2: KPIs Correlation Matrix}

\begin{tabular}{|c|c|c|c|c|c|c|c|c|c|}
\hline & & 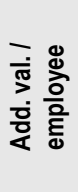 & 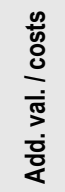 & 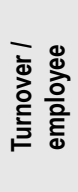 & 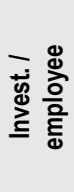 & $\frac{\text { 苟 }}{\stackrel{0}{0}}$ & 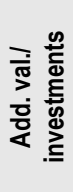 & 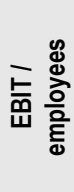 & 톨 \\
\hline \multirow[t]{2}{*}{$\begin{array}{l}\text { Added value / } \\
\text { employee }\end{array}$} & Correl. & 1 & -.058 & .490 & $\underset{* *}{647}$ & -.021 & -.053 & .874 & .427 \\
\hline & Signif. & & .072 & .000 & .000 & .524 & .099 & .000 & .000 \\
\hline \multirow[t]{2}{*}{$\begin{array}{l}\text { Added value / } \\
\text { costs }\end{array}$} & Correl. & -.058 & 1 & -.568 & $\underset{* *}{-.248}$ & .483 & .301 & .077 & .248 \\
\hline & Signif. & .072 & & .000 & .000 & .000 & .000 & .018 & .000 \\
\hline \multirow[t]{2}{*}{$\begin{array}{l}\text { Turnover / } \\
\text { employee }\end{array}$} & Correl. & .490 & -.568 & 1 & .426 & -.310 & -.065 & .340 & .143 \\
\hline & Signif. & .000 & .000 & & .000 & .000 & .046 & .000 & .000 \\
\hline \multirow[t]{2}{*}{$\begin{array}{l}\text { Investments / } \\
\text { employee }\end{array}$} & Correl. & .647 & -.248 & .426 & 1 & .359 & -.560 & .476 & -.069 \\
\hline & Signif. & .000 & .000 & .000 & & .000 & .000 & .000 & .034 \\
\hline \multirow[t]{2}{*}{$\begin{array}{l}\text { Investments / } \\
\text { costs }\end{array}$} & Correl. & -.021 & $\underset{* *}{.483}$ & -.310 & .359 & 1 & -.449 & .009 & -.165 \\
\hline & Signif. & .524 & .000 & .000 & .000 & & .000 & .773 & .000 \\
\hline \multirow[t]{2}{*}{$\begin{array}{l}\text { Added value / } \\
\text { investments }\end{array}$} & Correl. & -.053 & .301 & -.065 & -.560 & -.449 & 1 & .049 & .417 \\
\hline & Signif. & .099 & .000 & .046 & .000 & .000 & & .132 & .000 \\
\hline \multirow[t]{2}{*}{$\begin{array}{l}\text { EBIT / } \\
\text { employees }\end{array}$} & Correl. & .874 & $\underset{*}{.077}$ & .340 & .476 & .009 & .049 & 1 & .640 \\
\hline & Signif. & .000 & .018 & .000 & .000 & .773 & .132 & & .000 \\
\hline \multirow[t]{2}{*}{$\begin{array}{l}\text { EBIT / } \\
\text { investments }\end{array}$} & Correl. & .427 & .248 & .143 & -.069 & -.165 & .417 & .640 & 1 \\
\hline & Signif. & .000 & .000 & .000 & .034 & .000 & .000 & .000 & \\
\hline
\end{tabular}




\section{Business Administration and Management}

and investments. Unfortunately, however, investments represent only a small proportion of total costs, and along with low food prices, this sector also has a low profit.

In order to find connections between partial Pls and find key performance indicator (KPIs), a correlation matrix was created, using the Pearson correlation coefficient:

Relative strong relationships between KPIs that use the number of employees as a weight, such as added value and investment (the higher the investment, the higher the added value), are obvious. However, it is essential to draw attention to the opposite relationship between investment per employee and valueadded relation to investments - the lower the investments per employee, the higher the value added per investments.

This confirms the positive effects of modernization and the introduction of smart technologies into production (replacing labour by capital). This is also evidenced by the strong relationship between the share of investments in total costs and the added value in relation to the total costs - the higher the share of the investment indicates the higher the value added in relation to the total costs. In the long run, profits will be reduced by increased costs due to increasing investments, but there will be a reduction in the number of employees in the long run (lower wage costs), and the company will become more competitive and less dependent on fluctuations in the labour market (see Tab. 2).

Based on the results of the correlation analysis, it is also possible to find key performance indicators-performance indicators that will not be in a statistically significant relationship. Based on these indicators, it will be possible to benchmark the performance of individual industries, other indicators, and absolute data values can then serve to identify the specific cause of different performance. The first key performance indicator, which provides a basic picture of industry performance and economic benefits, is the value added in relation to cost. The growth of this $\mathrm{KPI}$ implies growth in the performance of the industry. The second key performance indicator is the EBIT in relation to one employee. If the value of this indicator increases, it means that the efficiency of the employees and thus the performance of

\section{Fig. 5: KPI 1 - Value added in relation to costs}

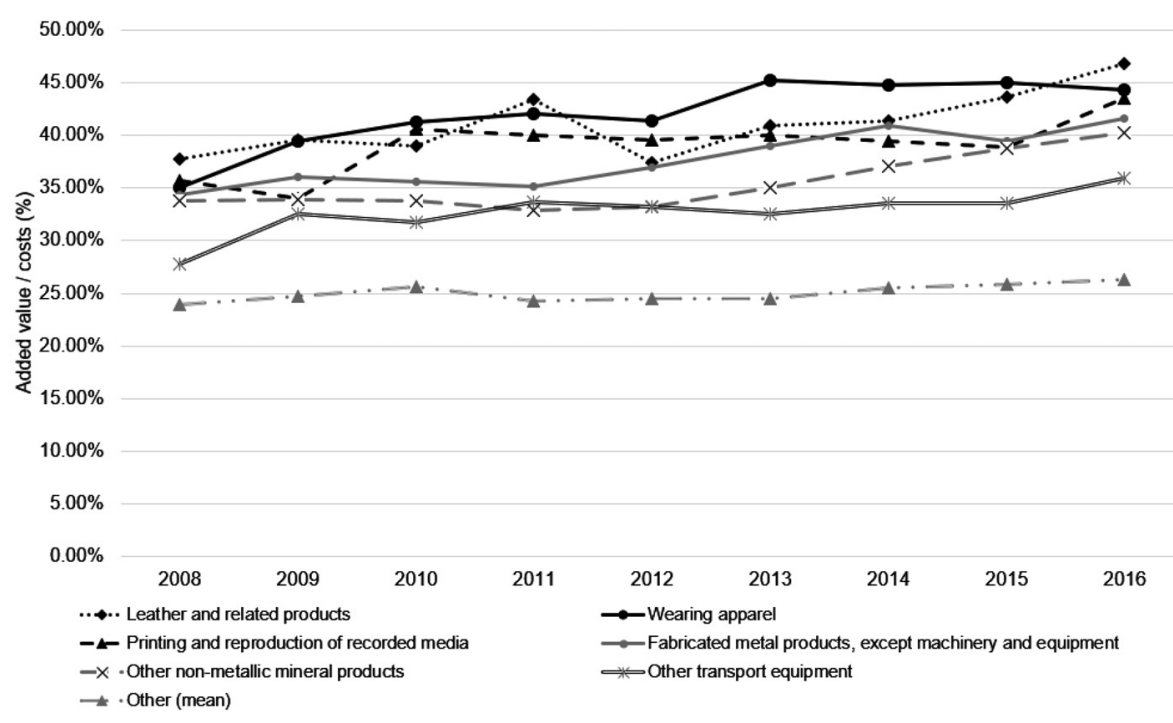


the entire industry is increasing. The third and final key performance indicator is the share of investments, which complements the previous indicators and broadens the performance perspective for the future as investments are one of the key factors that can increase production efficiency in subsequent periods.

The value of the first performance indicator (value added in relation to cost) is interesting for each industry sector (see Fig. 5). Nevertheless, the leather industry is rather marginal in the Czech Republic but creating the highest added value in terms of cost - almost $47 \%$. Similarly, the wearing apparel production sector (44\%), the printing and reproduction of recorded media sector $(43 \%)$ or the metalworking and metalworking sector, excluding machinery and equipment $(42 \%)$, also generate a similar value added in relation to costs. By contrast, the manufacture of motor vehicles (excluding motorcycles), trailers and semi-trailers produces relatively low added value $(18 \%)$ in relation to costs, which can be attributed in particular to high production costs (wages).

According to the second key performance indicator (EBIT per employee), the performance of individual industries differs significantly (see Fig. 6). In recent years, the highest earnings per employee generated beverage production (CZK 681 thousand), as well as manufacture of chemicals and preparations (CZK 525 thousand), manufacture of motor vehicles (CZK 492 thousand) and manufacture of rubber and plastic products (CZK 422 thousand) (figures are presented for 2016). However, despite the high added value in terms of cost, the production of clothes is at least profit-earning, with a profit of CZK 130 thousand per employee is caused by cheap products imported from eastern countries.

The third key performance indicator extends the previous two KPIs into the future sight as it evaluates the ratio of investment to total costs in the case of efficient investments, performance increases may be expected in subsequent periods. On the basis of the indicator's values, it cannot be unequivocally stated that an industry sector differs significantly from another industry sector because investments in almost all sectors amount to for around $8 \%$ of total costs (see Fig. 7). In the long-term (since 2008), the largest share of investments is in the printing

\section{Fig. 6: KPI 2 - Earnings before Interest and Taxes (EBIT) per employee}

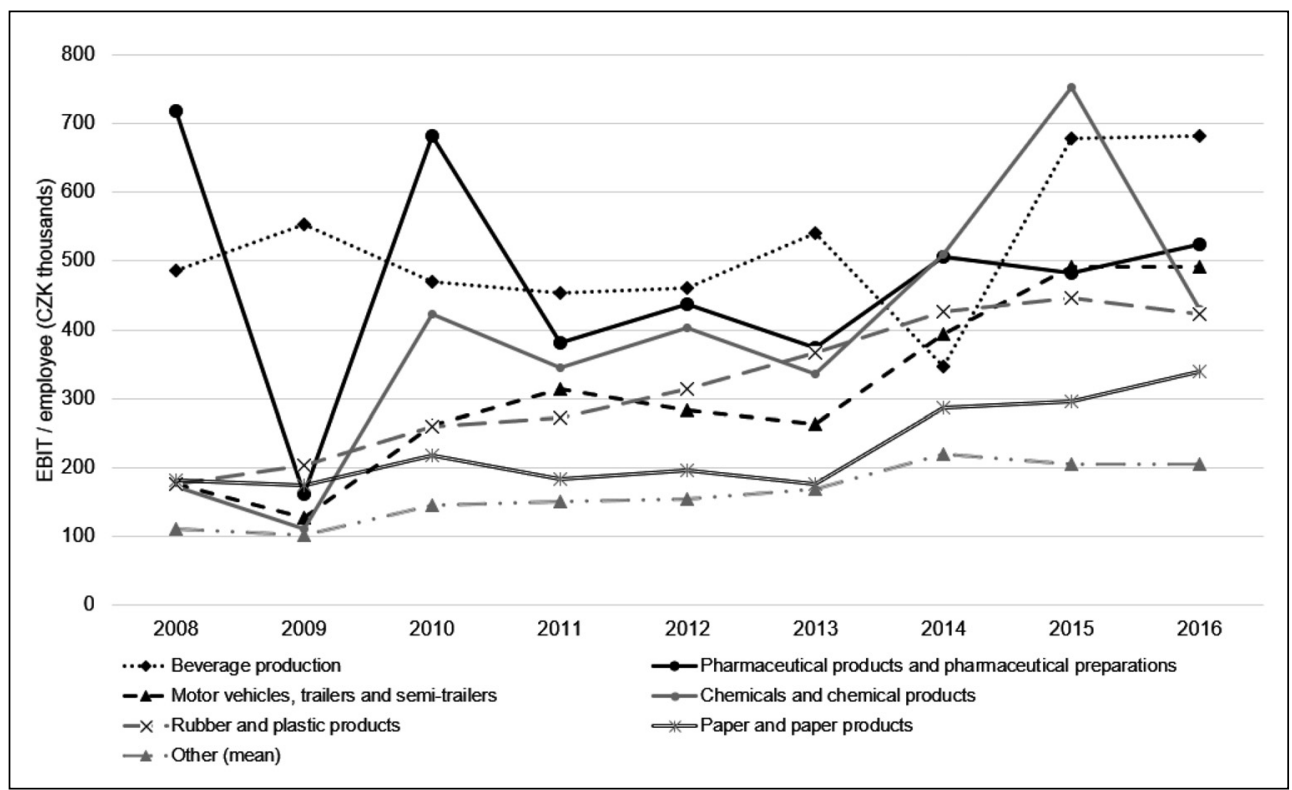




\section{Fig. 7: KPI 3 - Share of investments of the total costs}

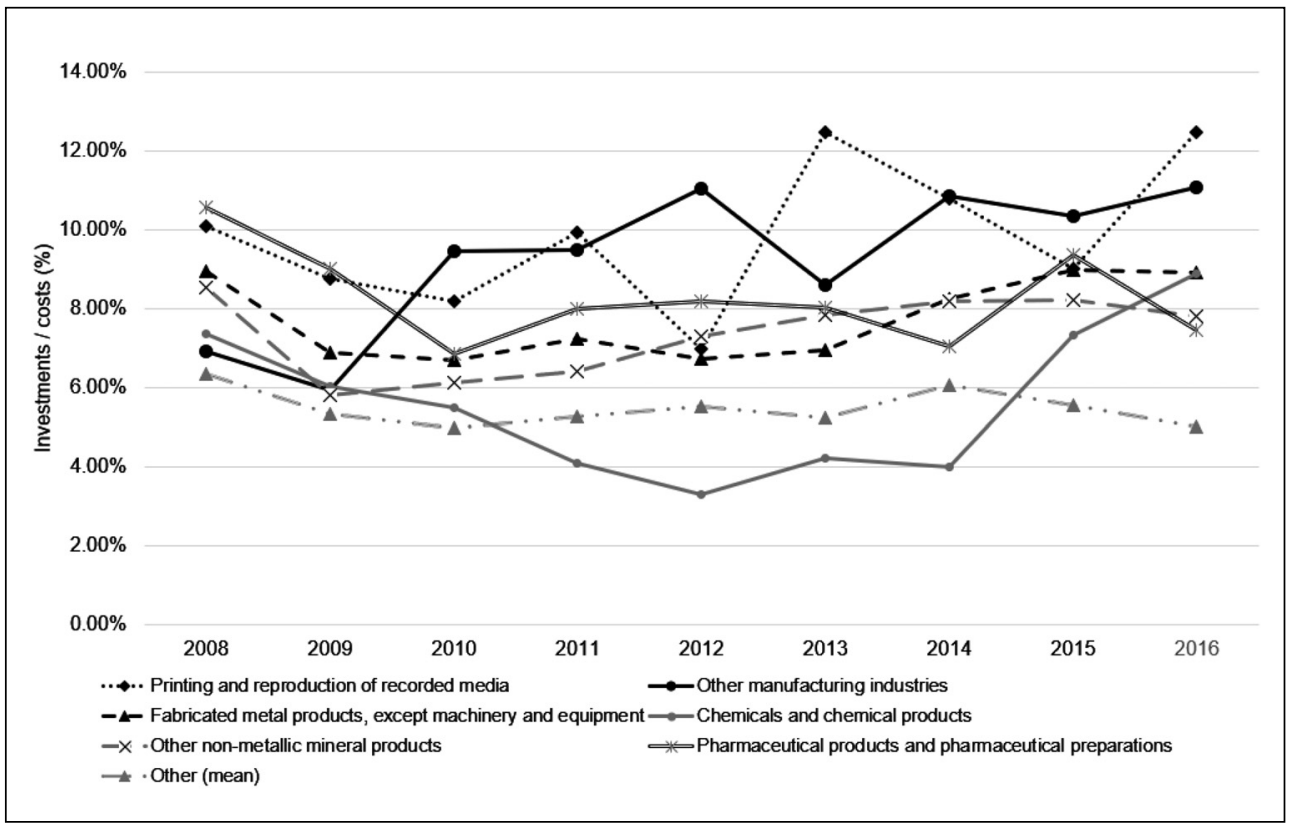

Source: own processing

and reproduction of recorded media $(9.9 \%)$, other manufacturing industries $(9.3 \%)$ and fabricated metal products, except machinery and equipment $(7.7 \%)$. Investments in the motor vehicle sector (except for motorcycles), trailers and semi-trailers amounted to an average of $5.1 \%$ of total costs in 2008-2016.

The key performance indicators show that all industries cannot be considered effective and efficient only on the basis of absolute values such as turnover, profits or share of GDP. While automobile production contributes significantly to GDP in the Czech Republic, which in terms of absolute indicators outperforms other industry sectors in turnover, profit, a number of employees and added value in terms of key performance indicators are among the less powerful. In terms of value added in relation to total production costs, it is only less than $18 \%$. This can be seen as a high threat. Wages (cost of production) increasing in the automotive industry may in the event of a decline in demand for cars and reducing their prices cause serious problems of the whole sector, and thus of Czech economy at all. This is evident from the development of the second performance indicator (earnings per employee) of the industry sector, which essentially had a similar development to the GDP of the Czech Republic in the course of the last 10 years.

On the other hand, some industry sectors in the Czech Republic are marginal from the point of view of absolute numbers, but they are very effective and efficient in terms of key performance indicators - for example, production of basic pharmaceutical products and pharmaceutical preparations or the production of alcoholic and non-alcoholic beverages. While these two sectors do not generate the greatest added value in terms of cost, they are very profitable, and they are not undervalued in terms of investment. One employee in the beverage industry brings the owners a profit of almost CZK 700 thousand per year, and one employee in the pharmaceutical industry brings CZK 524 thousand per year. In addition, the beverage production sector is not influenced by major problems caused by the economic recession and its profitability is relatively stable. 


\section{Discussion}

Nowadays, to be able to stay in the competitive environment, organizations have come to the understanding, that monitoring of enterprise processes is one of the ways to achieve better efficiency, performance, and overview (Kaganski et al., 2017). Key Performance Indicators (KPIs) are important for monitoring the performance in the industry. They can be used to identify poor performance and the improvement potential. KPIs can be defined for individual equipment, sub-processes, and whole plants. Different types of performances can be measured by KPIs, for example, energy, raw-material, control \& operation, maintenance, etc. Lindberg et al. (2015).

With the development of initiatives Industry 4.0 , it is important to measure the performance of individual activities, industry and the whole economy. For this reason, companies are looking for new indicators to measure this effectiveness. Worldwide, KPI is one of the most appropriate indicators. For example, the National Economic Council of the Government (NERV) has proposed a KPI for qualified assessment of public administration activities and the provision of a basis to government and government officials for its effective management. To a large extent, KPI indicators are used in public administration e.g. in the UK, Canada or New Zealand (Vláda České republiky, 2013). The industry has a dominant role in the Czech Republic. Regarding technological readiness, the Czech Republic is doing better than the other Visegrad countries (Svobodová et al., 2017).

Due to the importance of the manufacturing industry and the speed of Industry 4.0's implementation of this industry, the analysis was focused on it. The manufacturing sector employed 29.9 million people in the EU in 2015. 2.1 million enterprises were classified to manufacturing in the EU in 2015. In value added terms, Germany was the largest EU Member State in 19 of the 24 manufacturing subsectors in 2015; Italy was largest in three (the textiles, wearing apparel, and leather and related products manufacturing subsectors); France was the largest for the manufacture of beverages and the manufacture of other transport equipment. The Slovak specialisation rate for the manufacture of motor vehicles, trailers and semi-trailers was very high and amounted to $8.5 \%$ of non-financial business economy value added. Equally remarkable was the Greek specialisation rate for the manufacture of food products which contributed to $5.7 \%$ of non-financial business economy value added. Other high specialisation ratios were recorded in Hungary for the manufacture of machinery and equipment n.e.c. (Division 28) and in Slovenia for the manufacture of fabricated metal products (Division 25) (Eurostat, 2018a).

The question in the discussion is how the current economic situation is reflected in measuring the efficiency and effectiveness of businesses and industries. At present, there is a very low unemployment rate that is below the natural rate of unemployment. Companies do not have enough workforce, demand for work exceeds supply, and due to economic growth, there are plenty of jobs that companies do not have enough labour. The economic situation allows a faster onset of initiatives Industry 4.0. One of the solutions to measure Industry 4.0's benefits are KPI indicators.

Our proposed performance measurement of the manufacturing industry could be used to measure the performance and efficiency of the manufacturing industry or other industries. At the same time, it can serve individual companies to evaluate the effectiveness of manufacturing processes or governments for assessing the economic performance of the sector.

\section{Conclusion}

With the onset of the fourth industrial revolution, known as Industry 4.0, labour is being substitution by capital. This brings about significant changes in the production processes, but also the need for new indicators to measure performance and efficiency.

Many companies use absolute indicators (such as sales, profits, ...) or financial indicators (such as asset turnover, return on assets, ...) to evaluate their performance and efficiency. A part of the scientific community uses this shortfall for extensive statistical analyses to identify weaknesses of the evaluation. However, these analyses are very complex for business managers or government and they do not usually understand them. The aim of this article was to point out that evaluating the performance of individual industries is not possible on the basis of absolute values (it is generally mistaken for the more efficient enterprise to be the bigger one) only. Therefore, a system of key performance indicators has been proposed 
in the paper, which makes it possible to find at first glance the hidden relations between the absolute indicators that businesses have. Moreover, the proposed system of key performance indicators is completely universal and can be used to assess the performance of different industries.

The KPIs and its correlation analysis show that the industrial sector, which may be classified as unimportant at first sight, may be the most efficient one and vice versa. At the same time, KPI analysis allows you to determine how individual industries are responsive to an economic recession. An example may be the several times mentioned the automotive industry, which represents a significant share of the Czech industry. In recent years, because of the economic growth, this sector has been successful, and many people see the problem only in labour shortages. However, in terms of key performance indicators, it appears that the expansion of this industry can be only temporary. The world market is glutted by cars, and the European pressure to reduce emission limits can be the cause of significant problems for the Czech automotive industry. The share of investment in this sector is relatively low, and these investments focus primarily on more efficient production than on more efficient operations (e.g. the development of electric vehicles). On the contrary, industrial sectors which produce autonomous consumption goods may not be seen as significant today, but due to the cyclical development of the economy, it can be assumed that their importance for the Czech economy will grow in the future.

This knowledge and monitoring of the further development of performance indicators and the Czech economy can be a means of gaining important information as to whether to invest more in individual industries.

At the same time, it provides sufficient information on whether to invest more in individual industrial sectors and replace human work by modern technologies or, on the contrary, whether these investments bring no added value and that it is, therefore, appropriate to stop them and leave these sectors to other (more competitive) countries. KPI indicators gain in importance in Industry 4.0.

The paper was written with the support of the specific project 2019 grant "Determinants of cognitive processes impacting the work performance" at the Faculty of Informatics and Management, University of Hradec Kralove, Czech Republic.

\section{References}

Ammara, R., Fradette, L., \& Paris, J. (2016). Equipment performance analysis of a Canadian Kraft mill. Part I: Development of new key performance indicators (KPI). Chemical Engineering Research and Design, 115, 160-172. https://doi.org/10.1016/j.cherd.2016.09.019.

Amrina, E., \& Yusof, S. M. (2011). Key performance indicators for sustainable manufacturing evaluation in automotive companies. In Proceedings of the 2011 IEEE, IEEM, 1093-1097. https://doi.org/10.1109/ IEEM.2011.6118084.

Balachandran, B., \& Williams, B. (2018). Effective governance, financial markets, financial institutions \& crises. Pacific-Basin Finance Journal, 50, 1-15, https://doi. org/10.1016/j.pacfin.2018.07.006.

Brundage, M. P., Bernstein, W. Z., Morris, K. C., \& Horst, J. A. (2017). Using Graph-based Visualizations to Explore Key Performance Indicator Relationships for Manufacturing Production Systems. Procedia CIRP, 61, 451-456. https://doi.org/10.1016/j. procir.2016.11.176.

Czech Statistical Office. (2018). GDP resources and uses - 4th quarter of 2017. Retrieved July 9, 2018, from https://www.czso. cz/csu/czso/ari/gdp-resources-and-uses-4quarter-of-2017.

Czech Statistical Office. (2019). Industry Time series. Retrieved January 31, 2019, from https://www.czso.cz/csu/czso/pru_cr.

Doucek, P., Maryška, M., \& Novotný, O. (2013). Analýza souladu obsahu ICT studijních oborů s požadavky praxe v České republice. E\&M Ekonomie a Management, 16(3), 148-161.

Eurostat. (2018). Manufacturing statistics - NACE Rev. 2. Retrieved May 29, 2018, from http://ec.europa.eu/eurostat/statisticsexplained/index.php/Manufacturing_ statistics_-_NACE_Rev._2.

Eurostat. (2018a).

Manufacturing statistics - NACE Rev. 2. Retrieved May 29, 2018, from https://ec.europa.eu/eurostat/ statistics-explained/index.php/Manufacturing_ statistics_-_NACE_Rev._2\#Structural_profile.

Fisher, A. G. B. (1939). Production, primary, secondary and tertiary. Economic Record, 15(1), 
24-38. https://doi. org/10.1111/j.1475-4932.1939. tb01015.x.

Gatautis, R. (2008). The Impact of ICT on Public and Private Sectors in Lithuania. Inzinerine Ekonomika-Engineering Economics, 59(4), 18-28.

Government Property Agency. (2018). Government Property Agency Business Plan 2018 to 2019. Retrieved July 9, 2018, from https://www.gov.uk/government/uploads/ system/uploads/attachment_data/file/696561/ GPA_Business_Plan_201819.pdf.

Hedvicakova, M. (2018). Unemployment and effects of the first work experience of university graduates on their idea of a job. Applied Economics, 50(31), 3357-3363. https://doi.org/10.1080/00036846.2017.1420895.

Hedvicakova, M., \& Král, M. (2018). Level of industry automation 4.0 in the Czech Republic and impact on unemployment. In European Financial Systems 2018. Proceedings of the 15th International Scientific Conference (pp. 160-167). Brno: Masaryk University.

Hofmann, E., \& Rüsch, M. (2017). Industry 4.0 and the current status as well as future prospects on logistics. Computers in Industry International Journal, 89, 23-34. https://doi. org/10.1016/j.compind.2017.04.002.

Hong, M. H., Lee, T. R., Kao, Ch. K., \& Hilletofth, P. (2015). Setting Organizational Key Performance Indicators. International Journal of Management, Knowledge and Learning, 4(2), 135-161.

Hudson, M., Smart, A., \& Bourne, M. (2001). Theory and practice in SME performance measurement systems. International Journal of Operations \& Production Management, 21(8), 1096-1115. https://doi.org/10.1108/ EUM0000000005587.

Kaganski, S., Majak, J., Karjust, K., \& Toompalu, S. (2017). Implementation of Key Performance Indicators Selection Model as Part of the Enterprise Analysis Model. Procedia CIRP. 63, 283-288. https://doi.org/10.1016/j. procir.2017.03.143.

Kang, N., Zhao, C., Li, J., \& Horst, J. A. (2016). Hierarchical structure of key performance indicators for operation management and continuous improvement in production systems. International Journal of Production Research, 54(21), 6333-6350. https://doi.org/10.1080/00207543.2015.1136082.

Kraftová, I., Doudová, I., \& Miláček, R. (2018). At the threshold of the fourth industrial revolution: who gets who loses. E\&M Ekonomie a Management, 21(3), 23-39. https://doi. org/10.15240/tul/001/2018-3-002.

Král, M., \& Hájek, L. (2018). Analysis of Parliamentary Elections Costs in the Czech Republic. In Hradec Economic Days, 8 (pp. 472-481). Hradec Králové: University of Hradec Králové.

Lahti, R. K. (1999). Identifying and integrating individual level and organizational level core competencies. Journal of Business and Psychology, 14(1), 59-75. https://doi. org/10.1023/A:1022906400927.

Lindberg, C. F., Tan, S. T., Jan, J. Y., \& Starfelt, F. (2015). Key Performance Indicators Improve Industrial Performance. Energy Procedia, 75, 1785-1790. https://doi. org/10.1016/j.egypro.2015.07.474.

Marais, G. (1981). Structural Changes in Manufacturing Industry 1916 to 1975 . South African Journal of Economics, 49(1), 16-27. https://doi.org/10.1111/j.1813-6982.1981. tb00686.x.

Marešová, P., Soukal, I., Svobodová, L., Hedvičáková, M., Javanmardi, E., Selamat, A., Krejcar, O. (2018). Consequences of Industry 4.0 in Business and Economics. Special Issue Economic Growth as a Consequence of the Industry 4.0 Concept. Economies, 6(3), 46. https://doi.org/10.3390/economies6030046.

Ministry of Industry and Trade. (2018a). Analýza vývoje ekonomiky ČR za 2. čtvrtletí 2017. Retrieved July 9, 2018, from https://www.mpo.cz/assets/cz/rozcestnik/ analyticke-materialy-a-statistiky/analytickematerialy/2018/1/Analyza_2Q_2017.pdf.

Ministry of Industry and Trade. (2018b). Panorama zpracovatelského průmyslu ČR. Retrieved September 9, 2018, from https://www.mpo.cz/cz/panorama-interaktivnitabulka.html.

Ministry of Interior. (2016). Analýza měření a hodnocení výkonu veřejné správy v České republice. Retrieved February 3, 2019, from https://www.mvcr.cz/soubor/4-analyza-sc-1-4hodnoceni-a-mereni-vykonu-vs-v-cr-f-pdf.aspx.

Peral, J., Maté, A., \& Marco, M. (2017). Application of Data Mining techniques to identify relevant Key Performance Indicators. Computer Standards \& Interfaces, 54(2), 76-85. https://doi.org/10.1016/j.csi.2016.09.009.

Půžová, K., \& Marešová, P. (2014). Czech Republic's Competitiveness in ICT Market. Procedia - Social and Behavioral 
Sciences, 109, 880-885. https://doi.org/10.1016/j. sbspro.2013.12.558.

Saboniene, A. (2010). The Evaluation of the Potential of Lithuanian Manufacturing Industry Structure on the Basis of $\mathrm{Cl}$ Index. Inzinerine Ekonomika-Engineering Economics, 61(4), 399-407.

Singh, K., \& Sultan, A. I. (2018). Modelling and Evaluation of KPIs for the Assessment of Sustainable Manufacturing: An Extrusion process case study. Materials Today: Proceedings, 5(2), 3825-3834. https://doi. org/10.1016/j.matpr.2017.11.636.

Srivastava, N., \& Maitra, R. (2016). Key Performance Indicators (KPI) in Hospitality Industry: An Emphasis on Accommodation Business of 5 Star Hotels of National Capital Region. International Journal of Research in Tourism and Hospitality (IJRTH), 2(1), 34-40. https://doi.org/10.20431/2455-0043.0201004.

Statistika\&My. (2018). Růst českého průmyslu pokračoval. Retrieved July 14, 2018, from http://www.statistikaamy.cz/2018/01/rustceskeho-prumyslu-pokracoval/.

Statistika\&My. (2019). Jak si vedl český průmysl v prvních třech čtvrtletích 2018. Retrieved January 31, 2019, from http://www. statistikaamy.cz/2019/01/jak-si-vedl-ceskyprumysl-v-prvnich-trech-ctvrtletich-2018/.

Stock, T., \& Seliger, G. (2016). Opportunities of Sustainable Manufacturing in Industry 4.0. Procedia CIRP, 40, 536-541. https://doi. org/10.1016/j.procir.2016.01.129.

Svobodova, L., \& Hedvicakova, M. (2017). Technological Readiness of the Czech Republic and the Use of Technology. Lecture Notes in Business Information Processing, 299,
670-678. https://doi.org/10.1007/978-3-31965930-5_53.

UNIDO. (2018). Industrial Development Report. Retrieved June 5, 2018, from https://www.unido.org/sites/default/files/2015-12/ EBOOK_IDR2016_FULLREPORT_0.pdf.

Vláda České republiky. (2013). Řízení vybraných oblastí veřejné správy pomocí KPI. Retrieved February 1, 2019, from: https://www.vlada.cz/assets/media-centrum/ aktualne/NERV_JanProchazka_KPI.pdf.

Volejníková, J., \& Lelek, T. (2012). Hospodářský růst $v$ éře nové ekonomiky. Scientific Papers of the University of Pardubice, Series $D, 21(39 / 1)$, 98-106.

Zdražil, P., \& Applová, P. (2016). Growth Disparities among Regions of the Visegrad Group Countries: An Evidence of Their Extent and Nature. E\&M Ekonomie a Management, 19(2), 37-53. https://dx.doi.org/10.15240/ tul/001/2016-2-003.

Ing. Martina Hedvičáková, Ph.D. University of Hradec Králové Faculty of Informatics and Management Department of Economics Czech Republic Martina.Hedvicakova@uhk.cz

Ing. Martin Král University of Hradec Králové Faculty of Informatics and Management Department of Economics Czech Republic Martin.Kral@uhk.cz 


\section{Abstract}

\section{BENEFITS OF KPIS FOR INDUSTRY SECTOR EVALUATION: THE CASE STUDY FROM THE CZECH REPUBLIC}

\section{Martina Hedvičáková, Martin Král}

Currently, there is a fourth Industrial Revolution known as Industry 4.0. This industrialization is characterized by structural changes in the substitution of labour by new technologies and capital. The paper focuses on the industrial sector, which is dominant in the Czech Republic and has a significant contribution to GDP and value added. It describes the current economic situation in Czech Republic and in European Union.

Many companies use absolute indicators (such as sales, profits, ...) or financial indicators (such as asset turnover, return on assets, ...) to evaluate their performance and efficiency. A Performance Indicator or Key Performance Indicator (KPl) is a term used by industry or professionals for assessing or type of performance measurement. The aim of the paper is to critically assess the performance evaluation of individual industries based on the absolute monitored indicators compared to the key performance indicators (KPIs). The paper contains a proposal for a KPIs system that would allow performance assessments of industry sectors, including a correlation analysis of these indicators, to allow for long-term relations. Therefore, it is possible to evaluate the performance of individual industry sectors by means of their aid.

At the same time, KPI provides sufficient information on whether to invest more in individual industrial sectors and replace human work by modern technologies or, on the contrary, whether these investments bring no added value and that it is therefore appropriate to stop them and leave this sector to other (more competitive) countries. KPI indicators gain in importance in Industry 4.0. Primary and secondary sources were used in the processing of the article.

Key Words: Industry, added value, EBIT, key performance indicators, GDP, correlation analysis.

JEL Classification: L16, E24, O33.

DOI: 10.15240/tul/001/2019-2-007 